\title{
PENERAPAN KESELAMATAN DAN KESEHATAN KERJA (K3) DALAM UPAYA PENCEGAHAN PENYEBARAN VIRUS COVID-19 PADA AREA KERJA PT. SEMEN PADANG
}

\author{
Ratu Mira Ferial \\ Peneliti pada PT. Altrak 1978 Cabang Padang dan Mahasiswa pada MAP FIS UNP \\ ratuferial.30@gmail.com
}

\begin{abstract}
The Ministry of State Owned Enterprises has issued a circular decree number S336/MBU/05/2020 asking all SOE President Directors to prepare anticipation for the scenario of "The New Normal" starting from May 25, 2020. As a follow-up the circular decree, PT. Semen Padang has carried out efforts to overcome the spread of the Covid-19 virus in the work area of PT. Semen Padang by forming the Covid-19 Team. This research aimed to determine how the occupational safety and health (K3) program was implemented in an effort to prevent the spread of the covid-19 virus in the work environment of PT. Semen Padang. This research was a descriptive qualitative with case study method. Data collection techniques used in this study were interviews and documentation. Resource persons are determined by non-probability sampling and the technique used is purposive sampling. The results showed that PT. Semen Padang has formed a Covid-19 Team which has established the Working Guidelines for The New Normal Conditions. This work guide contains several modules which must be obeyed by all employees and other parties related to PT. Semen Padang, including the work module, the WFH module, the meeting module, the official travel module, the food/ drink module, the prayer module, the wearing mask module, the driving module, the corporate public facility usage module, the cleaning officer module and security module.
\end{abstract}

Keywords: Occupation health and safety, Covid-19, new normal era

Submitted: September 29, $2020 \quad$ Reviewed: November 19, $2020 \quad$ Published: November 24, 2020

How to Cite: Ferial, Ratu Mira. 2020. Penerapan Keselamatan dan Kesehatan Kerja (K3) dalam Upaya Pencegahan Penyebaran Virus Covid-19 pada Area Kerja PT. Semen Padang. Vol 4 (2): pp. 271-284. DOI: https://doi.org/10.24036/jess.v4i2

\section{Pendahuluan}

Saat ini dunia tengah dihadapkan dengan munculnya pandemi virus Covid-19. Virus yang pada awalnya berkembang di Kota Wuhan China pada Desember 2019 lalu, kini telah menyebarluas hampir ke seluruh dunia termasuk Indonesia. Hingga 30 Agustus 2020 organisasi kesehatan dunia (WHO) telah mencatat terdapat 25 Juta kasus virus Covid-19 diseluruh negara di dunia. Pemerintah Indonesia melalui Gugus Tugas Percepatan Penanganan Virus Covid-19 telah mencatat sebanyak 177.571 kasus hingga 1 September 2020 (www.covid19.go.id). Penyebaran virus Covid-19 saat ini semakin mengkhawatirkan, bahkan penyebarannya telah berkembang pada area perkantoran. Kota Padang merupakan salah satu kota di 
Indonesia dengan jumlah tingkat penularan virus Covid-19 cukup tinggi telah mencatat lebih dari 2.000 kasus hingga September 2020.

Tabel 1. Data Jumlah Kasus Penyebaran Covid-19 di Provinsi Sumatera Barat Per 6 September 2020

\begin{tabular}{|c|c|c|c|c|}
\hline No & $\begin{array}{c}\text { Kab/Kota di } \\
\text { Sumatera Barat }\end{array}$ & $\begin{array}{c}\text { Jumlah Kasus } \\
\text { Konfirmasi } \\
\text { Positif } \\
\end{array}$ & $\begin{array}{c}\text { Jumlah Kasus } \\
\text { Sembuh }\end{array}$ & $\begin{array}{c}\text { Jumlah } \\
\text { Kasus } \\
\text { Meninggal } \\
\end{array}$ \\
\hline 1 & Kota Padang & 1.266 & 873 & 37 \\
\hline 2 & Kab Agam & 186 & 41 & 3 \\
\hline 3 & $\begin{array}{l}\text { Kab Padang } \\
\text { Pariaman }\end{array}$ & 132 & 32 & 2 \\
\hline 4 & Kota Pariaman & 92 & 12 & 0 \\
\hline 5 & Kab Tanah Datar & 56 & 40 & 0 \\
\hline 6 & $\begin{array}{l}\text { Kota Padang } \\
\text { Panjang }\end{array}$ & 56 & 40 & 0 \\
\hline 7 & $\begin{array}{l}\text { Kota } \\
\text { Payakumbuh }\end{array}$ & 54 & 29 & 0 \\
\hline 8 & Kab 50 Kota & 47 & 18 & 1 \\
\hline 9 & Kab Pasaman & 6 & 5 & 0 \\
\hline 10 & $\begin{array}{l}\text { Kab Pasaman } \\
\text { Barat }\end{array}$ & 26 & 6 & 0 \\
\hline 11 & Kota Sawahlunto & 37 & 19 & 1 \\
\hline 12 & Kab Sijunjung & 17 & 12 & 1 \\
\hline 13 & Kota Solok & 70 & 46 & 1 \\
\hline 14 & Kab Solok & 49 & 31 & 3 \\
\hline 15 & Kab Dharmasraya & 41 & 34 & 0 \\
\hline 16 & $\begin{array}{l}\text { Kab Solok } \\
\text { Selatan }\end{array}$ & 13 & 9 & 0 \\
\hline 17 & $\begin{array}{l}\text { Kab Pesisir } \\
\text { Selatan }\end{array}$ & 41 & 29 & 1 \\
\hline
\end{tabular}

Berdasarkan Tabel 1 di atas dapat diketahui bahwa Kota Padang menempati urutan pertama untuk jumlah kasus konfirmasi positif tertinggi di Provinsi Sumatera Barat yakni sebanyak 1.266 kasus (sumbarprov.go.id). Angka ini sangat jauh dibandingkan dengan sejumlah Kota/Kabupaten lainnya di Sumatera Barat. Pekerja, Pengusaha dan Pemerintah saat ini menghadapi tantangan besar dalam upaya memerangi pandemi Covid-19 serta melindungi keselamatan dan kesehatan di tempat kerja. Untuk menghadapi kondisi pandemi saat ini pemerintah telah mengeluarkan beberapa kebijakan seperti kebijakan kartu prakerja dan pemberian insentif bagi tenaga medis (Marshal, Kerenhapukh Milka Tarmadi Putri, and Niken Febriana Dwi 2020). Selain kebijakan di atas dalam mengatasi penyebaran Covid19 baik pemerintah maupun pelaku usaha telah melakukan berbagai upaya agar penyebaran virus Covid-19 dapat dicegah dan diatasi terutama penyebaran virus Covid-19 dikawasan perkantoran dengan menerapkan aturan New Normal atau adaptasi kebiasaan baru ditempat kerja melalui program Keselamatan dan Kesehatan Kerja (K3). Keselamatan dan Kesehatan Kerja menunjuk pada kondisi 
fisikal psikologis-fisiologis tenaga kerja yang disebabkan oleh lingkungan kerja yang disediakan oleh perusahaan. Jika perusahaan melaksanakan keselamatan dan kesehatan kerja dengan baik maka hal ini akan efektif untuk mengurangi jumlah tenaga kerja yang mengalami kecelakaan, penyakit, cedera dan lainnya selama melakukan pekerjaan.

Pemerintah menghimbau semua perusahaan dan pelaku usaha untuk menerapkan keselamatan dan kesehatan kerja (K3) di lingkungan atau area kerja masing-masing, agar tetap produktif sehingga aktivitas ekonomi dapat berjalan aman dan sehat. Pelaksanaan keselamatan dan kesehatan kerja memberikan pengaruh besar terhadap peningkatan produktivitas kerja (Jati Kusuma and Darmastuti 2010). Selain itu dengan penerapan keselamatan dan kesehatan kerja dapat membentuk perilaku pekerja terhadap keselamatan dan kesehatan kerja (Christina, Ludfi, and Thoyib 2012) sehingga pekerja lebih siap untuk menghadapi kondisi pandemi seperti saat ini. Program keselamatan dan kesehatan kerja merupakan salah satu faktor penting yang harus dilaksanakan dalam upaya untuk mempertahankan keberlangsungan usaha dan perlindungan pekerja atau buruh dalam rangka pencegahan penyebaran virus Covid-19 serta penanggulangan Covid19 di lingkungan kerja. Apabila syarat-syarat keselamatan dan kesehatan kerja (K3) dilaksanakan sesuai dengan ketentuan peraturan perundang-undangan dan menerapkan budaya keselamatan dan kesehatan kerja (K3) serta melaksanakan standar dan protokol kesehatan yang ditetapkan oleh Kementrian Kesehatan, maka tempat kerja dapat terhindar dari penyebaran Covid-19. Hal ini sejalan dengan hasil penelitian M. Rizqi Agustino dkk ( Perdana et al., 2020) yang menunjukkan bahwa sebagai dampak pandemi virus Covid-19 seluruh HRD perusahaan dituntut untuk mampu mempelajari dan memahami mengenai protokol kesehatan serta melaksanakan keselamatan dan kesehatan kerja.

Fahrul Azwar BSN (2020) mengemukakan jika penerapan keselamatan dan kesehatan kerja (K3) dapat mendukung penerapan "new normal" di area perkantoran. Pelaksanaan keselamatan dan kesehatan kerja (K3) dapat mengacu pada SNI ISO45001:2018 (Sukanta, Sari, and Musadad 2020). Menteri Kesehatan Republik Indonesia dr. Terawan Agus Putranto menyatakan dunia usaha dan tenaga kerja berkontribusi besar untuk memutus mata rantai penyebaran virus Covid-19 karena besarnya jumlah populasi tenaga kerja serta besarnya mobilitas dan interaksi penduduk yang umumnya terbentuk dari aktifitas bekerja. Tempat kerja sebagai pusat interaksi dan tempat berkumpulnya orang-orang merupakan salah satu faktor risiko yang perlu diantisipasi penularannya. Melalui Surat Keputusan Menteri Kesehatan Nomor HK.01.07/MENKES/328/2020, Menteri Kesehatan menetapkan panduan pencegahan dan pengendalian virus Covid-19 atau panduan kerja New Normal di area perkantoran dan industri dengan tujuan untuk mendukung keberlangsungan usaha dalam menghadapi situasi pandemi seperti saat sekarang ini (sumber: http://promkes.kemkes.go.id/ diakses 6 September 2020).

PT. Semen Padang merupakan salah satu perusahaan berskala nasional yang ikut merasakan pengaruh pandemi Covid-19. Untuk menjamin keselamatan dan kesehatan para karyawan dari penyebaran virus Covid-19 PT. Semen Padang telah menetapkan Panduan Kerja Kondisi The New Normal sebagai bentuk penerapan keselamatan dan kesehatan kerja (K3) di area kantor. Panduan kerja ini telah 
dipersiapkan oleh Tim Covid-19 PT. Semen Padang. Menurut Undang-undang No. 1 Tahun 1970 penerapan kesehatan kerja adalah kewajiban perusahaan yang harus dilaksanakan. Dalam Pasal 3 dijelaskan bahwa tujuan penerapan kesehatan kerja antara lain : 1) Mencegah serta mengendalikan timbulnya penyakit baik physic atau physicis, penularan, infeksi dan keracunan; 2) Memperoleh penerangan yang cukup dan sesuai; 3) Memelihara kebersihan, kesehatan dan ketertiban; 4) Menyelenggarakan penyegaran udara yang cukup.

Berdasarkan latar belakang tersebut pada artikel ini akan membahas mengenai pelaksanaan program Keselamatan dan Kesehatan Kerja (K3) dalam upaya pencegahan penyebaran virus Covid-19 di lingkungan kerja PT. Semen Padang. Tujuannya adalah untuk mengetahui bagaimana pelaksanaan program keselamatan dan kesehatan kerja yang dilakukan oleh PT. Semen Padang dalam upaya melindungi keselamatan dan kesehatan kerja seluruh karyawannya dari penyebaran virus Covid-19 agar tidak mengganggu aktivitas perkantoran serta mengganggu produktivitas kerja karyawan serta pihak lain yang berkaitan dengan PT. Semen Padang.

\section{Tinjauan Kepustakaan}

\section{Kesehatan dan Keselamatan Kerja (K3)}

Tenaga kerja adalah salah satu aset penting yang dimiliki oleh sebuah organisasi atau perusahaan. Untuk itu organisasi atau perusahaan harus memberikan perlindungan dalam bentuk keselamatan dan kesehatan kerja (K3) kepada para tenaga kerjanya dari berbagai potensi bahaya dan ancaman terkait pekerjaan yang dilakukannya. Hal ini sesuai yang diamanatkan dalam Undang-undang nomor 13 tahun 2003 tentang ketenagakerjaa, dimana setiap tenaga kerja berhak untuk memperoleh keselamatan dan kesehatan dalam pelaksanaan pekerjaan yang diberikan oleh perusahaan. Untuk itu perusahaan harus menerapkan sistem manajemen keselamatan dan kesehatan kerja. Leon C. Meggison (dalam Mangkunegara, 2017) menjelaskan bahwa istilah keselamatan mencakup resiko keselamatan dan kesehatan. Namun istilah tersebut berbeda jika dikaji dari bidang kepegawaian. Keselamatan kerja diartikan sebagai kondisi yang aman dan selamat dari penderitaan, kerugian dan kerusakan di tempat kerja. Sementara kesehatan kerja terkait kondisi yang bebas dari gangguan mental, fisik, emosi dan rasa sakit yang disebabkan lingkungan kerja.

Tenaga kerja diberikan jaminan keselamatan dan meningkatkan derajat kesehatan dilakukan dengan melakukan tindakan pencegahan terjadinya kecelakaan dan penyakit yang disebabkan pekerjaan, mengurangi atau mengendalikan efek negatif ditempat kerja, pengobatan atau rehabilitasi serta penyuluhan kesehatan. Hal ini bertujuan agar tenaga kerja dapat bekerja optimal (Hakim 2014). Menurut Hariandja setiap perusahaan dan pelaku usaha berkewajiban untuk memelihara tempat kerja yang sehat dan aman bagi seluruh tenaga kerja, mematuhi syarat dan standar kerja.

Sementara itu tujuan keselamatan dan kesehatan kerja antara lain (Mangkunegara 2017) : 
a. Memberikan jaminan keselamatan dan kesehatan secara fisik, psikologis dan sosial bagi setiap karyawan atau pekerja;

b. Penggunaan peralatan dan perlengkapan kerja seefektif mungkin

c. Pemeliharaan keamanan seluruh hasil produksi

d. Memberikan jaminan terhadap pemeliharaan dan peningkatan kesehatan gizi pegawai

e. Meningkatkan partisipasi kerja, keserasian serta gairah kerja

f. Melindungi pekerja dari gangguan kesehatan yang disebabkan kondisi dan lingkungan kerja

g. Memberikan rasa aman bagi seluruh karyawan atau pekerja dalam melaksanakan pekerjaannya

Penerapan keselamatan dan kesehatan kerja diharapkan menjamin konsistensi dan efktivitas perusahaan dalam meminimalisir, mengurangi dan mencegah resiko kecelakaan dan penyakit akibat kerja. Hal ini dilakukan untuk menjaga produktivitas kerja karyawan dengan melibatkan unsur tenaga kerja, manajemen perusahaan, kondisi dan lingkungan kerja yang terintegrasi agar tercipta suasana kerja yang aman dan produktif (Mardhatillah 2017). Sejalan dengan hal ini hasil penelitian mengenai penerapan keselamatan dan kesehatan kerja menunjukkan memiliki pengaruh yang positif dan signifikan terhadap produktivitas kerja karyawan (Mardi Astutik and Retno Catur Kusuma Dewa 2019).

Setiap perusahaan harus membiasakan kehidupan new normal untuk mengikuti protokol kesehatan di lingkungan atau area kerja perusahaan sesuai dengan instruksi pemerintah (Sukanta et al. 2020). Dengan pelaksanaan keselamatan dan kesehatan kerja (K3) diharapkan dapat memberikan perlindungan bagi para pekerja dari gangguan kesehatan akibat kondisi saat ini agar produktivitas kerja tetap terjaga. Hal ini sejalan dengan hasil penelitian Friska Ayu et al. (2019) bahwa keselamatan dan kesehatan kerja berpengaruh pada produktivitas kerja karyawan. Berdasarkan hasil penelitian tersebut dapat diketahui bahwa keselamatan dan kesehatan kerja sangat penting pelaksanaannya pada suatu organisasi atau perusahaan. Selain sebagai bentuk jaminan keselamatan dan kesehatan bagi seluruh tenaga kerja atau karyawan, namun juga sebagai upaya bagi organisasi atau perusahaan untuk meningkatkan produktivitas dan prestasi kerja karyawan.

Hal senada juga disampaikan Wahyuni et al. (2018) bahwa keselamatan dan kesehatan kerja merupakan salah satu program yang dapat meningkatkan produktivitas kerja. Dimana keselamatan dan kesehatan kerja berpengaruh positif dan signifikan terhadap produktivitas kerja karyawan. Ahmad Zainul Arifin \& Feri Harianto (2020) dalam penelitiannya juga menjelaskan jika dengan penerapan keselamatan dan kesehatan kerja berpengaruh signifikan terhadap produktivitas kerja. Berdasarkan uraian diatas, maka penulis menyimpulkan bahwa keselamatan dan kesehatan kerja memiliki peranan penting dalam sebuah organisasi baik organisasi pemerintah maupun swasta karena sangat berpengaruh pada produktivitas kerja. Di tengah kondisi pandemi saat ini untuk menjaga agar karyawan tetap produktif maka sangat penting diterapkan keselamatan dan kesehatan kerja agar roda perekonomian bisa terus berjalan. 


\section{Metode Penelitian}

Jenis penelitian ini adalah penelitian deskriptif kualitatif dengan metode studi kasus. Metode studi kasus digunakan pada penelitian ini karena dapat menafsirkan fenomena nyata yang terjadi pada pelaksanaan program keselamatan dan kesehatan kerja sebagai upaya untuk mengatasi penyebaran virus Covid-19 di area kerja PT. Semen Padang yang diwujudkan dalam Panduan Kerja Kondisi The New Normal.

Pada penelitian ini pengumpulan data dilakukan dengan menggunakan teknik wawancara dan studi dokumentasi. Akibat adanya pandemi Covid-19 ini wawancara dilakukan melalui media Zoom dan Whatsapp. Narasumber ditentukan dengan non probabilty sampling menggunakan teknik purposive sampling. Narasumber pada penelitian ini adalah Divisi HSE PT Semen Padang dipilih karena divisi ini merupakan divisi yang melaksanakan tugas untuk melaksanakan program keselamatan dan kesehatan kerja (K3) di PT. Semen Padang. Uji validitas dan reliabilitas menggunakan trianggulasi sumber. Tekhnik analisis data yang digunakan yaitu deskriptif.

\section{Hasil Penelitian dan Pembahasan}

Kementerian BUMN telah menetapkan surat edaran nomor S-336/MBU/05/2020 yang meminta seluruh Direktur Utama BUMN mempersiapkan skenario 'The New Normal' sejak 25 Mei 2020. Kementerian BUMN mewajibkan setiap BUMN harus membentuk Task Force Penanganan Covid-19 serta wajib menyusun protokol penanganan Covid-19, kewajiban Task Force Penanganan Covid-19 menyusun timeline pelaksanaan skenario The New Normal, dan kewajiban BUMN agar mengampanyekan gerakan optimisme dalam menghadapi The New Normal.

Sebagai upaya untuk mencegah penyebaran virus Covid-19 di area kerja, PT. Semen Padang telah membentuk tim khusus untuk penanganan Covid-19 yakni Tim Task Force penanganan Covid-19 PT. Semen Padang. Pembentukan tim ini berdasarkan Surat Edaran Kementrian BUMN tanggal 15 Mei 2020 perihal antisipasi skenario The New Normal BUMN. Tim ini telah berhasil menyiapkan protokol atau Panduan Kerja Kondisi 'The New Normal' yang mulai berlaku 1 Juni 2020. Panduan kerja kondisi 'The New Normal' telah disosialisasikan baik kepada insan PT Semen Padang maupun pada pihak terkait lainnya. Panduan kerja ini tidak hanya mengatur hal-hal yang berkaitan dengan aspek manusia (human capital \& culture), cara kerja (process \& technology), namun juga berkaitan dengan pelanggan, pemasok, mitra, dan stakeholders lainnya (business continuity).

Sosialisasi panduan kerja kondisi The New Normal kepada para pemangku kepentingan (stakeholders) dilakukan pada Rabu 27 Mei 2020. Sosialisasi ini dilakukan dengan sasarannya adalah perangkat Kerapatan Adat Nagari (KAN), Kecamatan, Local Comunity Organizer (LCO) dan Forum Nagari di sekitar lingkungan kerja PT. Semen Padang. Safety Officer PT Semen Padang bapak Indra Mardeni yang diwawancara tanggal 2 September 2020 mengemukakan jika sosialisasi tersebut dilakukan agar semua pihak dapat memahami aturan yang diterapkan oleh perusahaan dalam rangka mencegah penyebaran virus Covid-19 di lingkungan kerja PT. Semen Padang. Dengan demikian tidak ada kesalahpahaman lagi, jika nantinya masyarakat yang hendak memasuki lingkungan perusahaan harus 
mengikuti aturan yang sudah dibuat dan dijalankan. Bapak Indra Mardeni juga menjelaskan sosialisasi yang diberikan kepada masyakat meliputi sejumlah aturan yang juga diberlakukan kepada karyawan dan orang yang bekerja di PT Semen Padang. Sosialisasi meliputi penerapan protokol Covid-19 dan melengkapi personal safety kit saat hendak memasuki area PT. Semen Padang. Aturan yang akan diberlakukan tersebut, juga disertai dengan sanksi.

Terdapat 12 modul dalam panduan kerja kondisi The New Normal PT Semen Padang. Dalam modul tersebut ditetapkan panduan dalam Work From Office (WFO), modul Work From Home, modul menerima tamu dokumen dan paket, modul rapat, modul perjalanan dinas, modul makan (katering/minum), modul beribadah salat, modul mengenakan masker, modul berkendaraan, modul pemakaian fasilitas umum perusahaan, modul petugas kebersihan dan modul pengamanan. Panduan Kerja Kondisi The New Normal PT Semen Padang yakni sebagai berikut:

Tabel 2

Panduan Kerja Kondisi The New Normal PT. Semen Padang

\begin{tabular}{ll}
\hline $\begin{array}{c}\text { Panduan Kerja Kondisi } \\
\text { The New Normal }\end{array}$ & \multicolumn{1}{c}{ Aturan } \\
\hline Modul Bekerja & $\begin{array}{l}\text { a. Seluruh karyawan diutamakan menggunakan } \\
\text { kendaraan pribadi, jika menggunakan kendaraan } \\
\text { umum harus sesuai dengan protokol kesehatan }\end{array}$ \\
& seperti menggunakan masker, menjaga jarak \\
& b. Jika karyawan yang menggunakan sepeda motor \\
& memakai sarung tangan dan helm \\
& c. Karyawan wajib menjaga kebersihan tempat kerja \\
& dan peralatan kerja menggunakan cairan desinfektan \\
& sebelum dan sesudah bekerja \\
d. Jika karyawan selesai melakukan pemeriksaan & lapangan maka harus mencuci tangan sebelum \\
& memasuki ruang kerja \\
Modul Work From Home & $\begin{array}{l}\text { a. Menyelesaikan tugas-tugas perusahaan dirumah } \\
\text { b. Karyawan harus membuat laporan harian atau log } \\
\text { book aktivitas WFH dan dilaporkan ke atasan setiap }\end{array}$ \\
& hari \\
c. Komunikasi intensif dengan atasan \\
d. Melakukan presensi online dengan aplikasi yang \\
telah disiapkan perusahan \\
e. Jika karyawan ingin meninggalkan rumah harus \\
mendapat izin atasan \\
f. Karyawan dilarang bepergian ke luar kota/ke luar \\
negeri untuk kepentingan pribadi \\
g. Menjaga kesehatan dan kebersihan diri dan \\
lingkungan tempat tinggal \\
h. Selalu memonitor kinerja dan posisi bawahan \\
i. Karyawan dilarang meninggalkan rumah pada jam \\
kerja tanpa seizing atasan
\end{tabular}


j. Bepergian (luar kota/luar negeri) dalam rangka kepentingan pribadi sesuai ketentuan perusahaan

Modul Menerima Tamu, a. Jam menerima tamu pukul $09.00-15.00$ WIB

Dokumen dan Paket

b. Tamu wajib mengisi formulir Self Assessmen dan menyerahkan formulir tamu kepada yang ditemui untuk ditandatangani

c. Jumlah tamu maksimal 4 orang/rombongan. Jika terdapat rombongan lebih banyak hanya diizinkan untuk situasi tertentu

d. Dilarang mengalamatkan perusahaan untuk pengiriman dan penerimaan paket pribadi kecuali kebutuhan makanan karyawan

e. Paket yang diterima harus disterilisasi terlebih dahulu menggunakan disinfektan

f. Resepsionis harus selalu menggunakan masker dan sarung tangan

Modul Rapat

a. Diutamakan menggunakan video conference

b. Jika rapat harus dilakukan tatap muka dilingkungan perusahaan, maksimal diikuti oleh 10 orang karyawan dan dilarang untuk berjabat tangan

c. Jika rapat dilakukan di luar perusahaan, karyawan wajib menggunakan masker, membawa handsanitizer dan dilarang berjabat tangan

Modul Perjalanan Dinas

a. Memiliki surat izin perjalanan dinas dan surat keterangan sehat dari dokter perusahaan

b. Dianjurkan menggunakan sarung tangan

c. Membawa obat-obatan/handsanitizer pribadi

d. Selalu mengkonsumsi makanan dan minuman yang higienis

e. Diutamakan bertransaksi non tunai

f. Melakukan presensi dengan aplikasi yang disediakan perusahaan

Modul Makan dan Minum a. Menggunakan peralatan makan dan minum sendiri

b. Diutamakan membawa makanan sendiri, makanan yang tidak dibawa sendiri harus higienis

c. Jika harus membeli makanan di luar lingkungan perusahaan harus menggunakan masker dan jaga jarak

d. Makanan harus mematuhi aturan makanan yang sehat dan bergizi

Modul Beribadah Shalat a. Membawa sajadah dan mukenah sendiri

b. Menjaga jarak dengan jamaah lain minimal 2 meter

c. Shalat jamaah dilakukan bergilir menyesuaikan dengan luas mushala 

Modul menggunakan
a. Masker kain yang digunakan harus berjenis minimal 2 lapis dan dicuci setiap hari menggunakan sabun masker
b. Masker jenis disposal hanya digunakan sekali pakai
Modul berkendara
a. Menjaga jarak, menggunakan masker dan sarung tangan jika menggunakan kendaraan umum
b. Mobil operasional wajib disterilisasi setiap hari
c. Jumlah penumpang maksimal $50 \%$ dari kapasitas mobil
d. Penumpang/sopir harus membawa handsanitizer

Model Pemakaian Fasum Perusahaan

Fasilitas Umum Perusahaan tidak boleh digunakan hingga perusahaan mengeluarkan aturan ketentuan penggunaan

Modul Petugas Kebersihan

a. Permukaan benda yang sering disentuh harus selalu dibersihkan seperti gagang pintu tombol lift dsb.

b. Petugas kebersihan harus menggunakan masker dan sarung tangan

c. Memeriksa dan mengisi ulang sabun dan handsanitizer

d. Penyemprotan disinfektan 2 kali seminggu

Modul Pengamanan

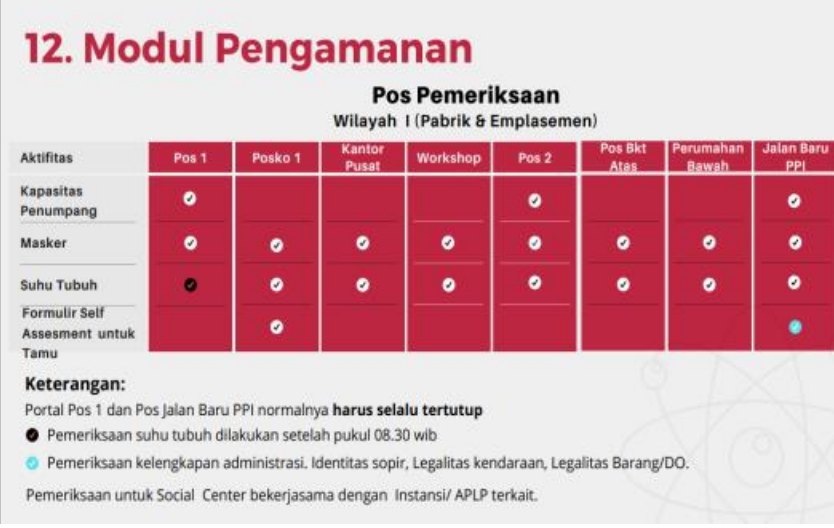

Gambar 1. Modul Pengamanan

Aturan yang berlaku untuk seluruh modul

a. Seluruh karyawan PT. Semen Padang serta pihak lain yang beraktivitas di lingkungan kerja PT. Semen Padang diwajibkan untuk mengenakan masker

b. Seluruh karyawan dilarang berkumpul atau bergerombol lebih dari 5 orang selain sedang bekerja

c. Dalam melaksanakan aktivitas wajib menjaga jarak dengan jarak minimal 2 meter. Jika jarak 2 meter tidak terpenuhi maka tidak diperkenankan melepaskan masker

d. Tidak boleh berjabat tangan 
e. Sering mencuci tangan dengan menggunakan sabun atau handsanitizer yang telah disediakan perusahaan

f. Selama bekerja tidak boleh berjalan bersisian

Tim Covid-19 menginstruksikan agar seluruh karyawan PT. Semen Padang menggunakan aplikasi FORCA ESS untuk kehadiran atau absensi serta sebagai media untuk pelaporan kondisi kesehatan karyawan. Baik karyawan yang melakukan pekerjaan dikantor (Work From Office) maupun karyawan yang melakukan pekerjaan dari rumah (Work From Home). Tim Covid-19 juga menegaskan bagi seluruh karyawan PT. Semen Padang untuk membatasi seluruh kegiatan diluar rumah, dengan tujuan agar karyawan tidak tertular virus Covid-19 yang dapat menyebarkannya dilingkungan kantor.

Dengan adanya panduan kerja The New Normal ini merupakan bukti kesungguhan manajemen PT. Semen Padang untuk membantu pemerintah dalam mengatasi penyebaran virus Covid-19 khususnya di area perkantoran dengan menerapkan protokol kesehatan. Serta sebagai wujud pelaksanaan program keselamatan dan kesehatan kerja pada masa adaptasi kebiasaan baru. Hal ini sejalan dengan hasil penelitian Muhammad Rizqi Agustino dkk yang dikutip dari Business Innovation \& Entrepreneurship Journal bahwa dimasa adaptasi dan kebiasaan baru ini setiap perusahaan dituntut untuk mempelajari dan memahami protokol kesehatan dan hal-hal yang berkaitan dengan keselamatan dan kesehatan kerja. Upaya ini dilakukan sebagai bentuk penyesuaian agar perusahaan tetap bertahan dalam menghadapi situasi pandemi seperti saat ini (Perdana et al. 2020).

Panduan kerja ini merupakan perubahan budaya yang harus ditaati oleh seluruh karyawan PT Semen Padang, SIG, APLP, distributor, pemasok serta stakeholders yang akan masuk, melintas dan bekerja pada area PT Semen Padang. Bagi karyawan yang melanggar panduan akan dikenakan sanksi sesuai dengan Perjanjian Kerja Bersama (PKB) atau peraturan perundang-undangan yang berlaku. Untuk mengantisipasi jika terdapat karyawan PT. Semen Padang yang sakit atau membutuhkan konsultasi kesehatan Tim Covid-19 PT. Semen Padang telah menyiapkan tim dokter yang dapat dihubungi oleh seluruh karyawan.

Organisasi Perburuhan Internasional (ILO) memprediksi jika pandemi ini berlangsung lama maka akan banyak tenaga kerja yang kehilangan pekerjaan, serta akan berpengaruh pada upah, akses perlindungan sosial dan kondisi kerja. Untuk mengantisipasi penyebaran virus Covid-19 di area kerja setiap pelaku usaha diharuskan untuk membuat rencana kelangsungan usaha. Pembuatan rencana kelangsungan usaha ini bertujuan agar pelaku usaha dapat mengidentifikasi serta meminimalisir resiko yang dapat mempengaruhi aktivitas usaha akibat virus Covid19 dengan mempersiapkan strategi untuk mengurangi dampak pandemi ini Pembuatan rencana kerja ini diharapkan dapat disesuaikan dengan pedoman pemerintah setempat serta harus dikomunikasikan kepada seluruh pelaku usaha dan para pekerja.

International Labour Organization (ILO) telah menetapkan Panduan Pencegahan dan Mitigasi Penyebaran Covid-19 di lingkungan kerja yang dapat dijadikan panduan tindakan praktis untuk mengurangi penyebaran pandemi Covid- 
19 di lingkungan kerja. Berikut panduan pencegahan dan Mitigasi Covid-19 yang ditetapkan oleh International Labour Organization (International Labour Organization 2020) :

a. Menjaga Jarak atau Social Distancing. Hal ini dilakukan dengan menjaga jarak interaksi antar pekerja serta konsumen dalam aktivitas usaha. Sebagai salah satu upaya untuk meminimalisir interaksi antar karyawan atau pekerja di lingkungan kantor maka dianjurkan penggunaan telepon, surat elektronik sebagai media komunikasi atau pelaksanan rapat atau disikusi secara virtual untuk mengurangi pertemuan tatap muka; pengaturan jadwal kerja dengan memberlakukan sistem shift untuk menghindari konsentrasi besar karyawan pada waktu tertentu di kantor atau area kerja

b. Menjaga kebersihan diri dengan rajin mencuci tangan. Menyediakan desinfektan untuk menjaga kebersihan area yang sering diakses oleh banyak orang seperti gagang pintu, tombol lift dsb dan handsanitizer atau handsoap untuk tangan sebagai upaya untuk mempromosikan budaya mencuci tangan; Menghimbau para pekerja untuk menutup mulut dan hidung dengan posisi siku menekuk atau menutup dengan tisu saat bersin dan batuk untuk menghindari penyebaran virus Covid-19..

c. Komunikasi dan Pelatihan. Hal tersebut dapat dilakukan dengan : a) Melatih manajemen dan karyawan atau mengenai upaya-upaya yang dapat dilakukan untuk mencegah risiko penularan virus Covid-19 serta bagaimana bertindak jika terjadi kasus infeksi Covid-19; b) Mengadakan pelatihan penggunaan, pemeliharaan, serta pembuangan alat pelindung diri (APD) yang baik dan benar; c) Menjalin komunikasi intensif dengan para pekerja atau karyawan untuk memberikan informasi terkini terkait situasi di area kerja, wilayah atau negara; d) menginformasikan pekerja tentang hak mereka untuk menyingkir dari situasi kerja yang menimbulkan bahaya serius bagi kehidupan atau kesehatan, sesuai dengan prosedur yang ditetapkan dan segera memberi tahu atasan langsung terkait situasi tersebut.

d. Alat pelindung diri (APD). Tersedianya Alat Pelindung Diri (APD) yang memadai dan tersedia tempat pembuangan tertutup secara higienis untuk pembuangan alat-alat tersebut.

e. Response. Seiring adanya panduan pemerintah, menghimbau karyawan atau para pekerja untuk tidak datang ke tempat kerja jika menunjukan gejala yang dicurigai virus Covid-19. Memberikan hak untuk cuti sakit, tunjangan sakit seluruh pekerja; Mempersiapkan fasilitas isolasi ditempat kerja bagi siapa saja yang mengidap gejala Covid-19 sambil menunggu pemindahan ke fasilitas; Melakukan penyemprotan disinfektan di lingkungan kerja; Serta melakukan pengawasan pengawasan kepada pihak-pihak yang melakukan kontak erat dengan pekerja yang terinfeksi virus Covid-19.

Selain itu ILO (International Labour Organization 2020) juga mengemukakan beberapa saran bagi para pekerja untuk menghadapi kondisi pandemi covid-19 saat ini antara lain : 
a. Organisasi pekerja diharapkan dapat meningkatkan partisipasinya dalam pengambilan keputusan sebagai respon terhadap krisis akibat pandemi covid-19.

b. Perlu diadakan dialog sosial antara pekerja, organisasi pekerja, perusahaan serta pemerintah secara efektif.

c. Memperhatikan kebersihan area kerja seperti penggunaan handsanitizer, disinfektan serta menghimbau bagi tenaga kerja untuk menjaga kesehatan.

d. Mendorong setiap tenaga kerja untuk bekerja sama dalam menghadapi pandemi.

\section{Penutup}

Sebagai bentuk tindak lanjut dari Surat Edaran Kementrian BUMN tanggal 15 Mei 2020 perihal Antisipasi Skenario The New Normal BUMN, PT. Semen Padang telah membentuk Tim Covid-19 yang telah menetapkan Panduan Kerja Kondisi The New Normal. Panduan kerja ini berisikan beberapa modul yang harus dipatuhi oleh seluruh karyawan dan pihak lain yang berkaitan dengan PT. Semen padang, diantaranya modul bekerja, modul WFH, modul rapat, modul perjalanan dinas modul makan/minum, modul beribadah sholat, modul menggunakan masker, modul berkendara, modul pemakaian fasum perusahaan, modul petugas kebersihan dan modul pengamanan.

Tim Covid-19 PT. Semen Padang juga menetapkan sanksi bagi karyawan yang tidak mematuhi panduan kerja kondisi The New Normal sesuai dengan Perjanjian Kerja Bersama (PKB) dan bagi selain karyawan yang tidak mematuhi dipersilahkan untuk meninggalkan area PT. Semen Padang untuk melengkapi persyaratan sebelum memasuki area PT. Semen Padang. Tim Covid-19 juga telah menyiapkan nomor telepon penting yang dapat dihubungi oleh karyawan jika terjadi sesuatu terkait penyebaran Covid-19 di area PT. Semen Padang. Tim Covid19 PT. Semen Padang meminta agar semua karyawan menjaga kesehatan dengan rutin berolahraga, makan makanan sehat, cukup istirahat, berpikiran positif dan beribadah.

Penulis menyarankan agar Tim Covid-19 PT. Semen Padang dapat melakukan evaluasi secara berkala terhadap pelaksanaan Panduan Kerja Kondisi The New Normal agar dapat diketahui sejauh mana efektivitas panduan kerja ini dalam mengatasi penyebaran virus Covid-19 di area kerja PT. Semen Padang. Selain itu penulis juga menyarankan agar penelitian lain terkait adaptasi kebiasaan baru atau New Normal di area kerja dapat terus dilakukan sehingga dapat membantu upaya pemerintah dalam mengatasi penyebaran Covid-19 serta memberikan perlindungan bagi seluruh tenaga kerja di Indonesia dimasa pandemi ini agar kondisi perekonomian Indonesia tetap kondusif dan para pelaku usaha atau perusahaan dapat bertahan dalam kondisi ini.

\section{DAFTAR KEPUSTAKAAN}

Ahmad Zainul Arifin, and Feri Harianto. 2020. "Pengaruh Penerapan Keselamatan Dan Kesehatan Kerja (K3) Terhadap Produktivitas Kerja Di Surabaya”. Jurnal 
Rekayasa Teknik Sipil Universitas Madura 5 No. 1.

Christina, Wieke Yuni, Djakfar Ludfi, and Armanu Thoyib. 2012. "Pengaruh Budaya Keselamatan Dan Kesehatan Kerja ( K3 ) Terhadap Kinerja Proyek Konstruksi." Jurnal Rekayasa Sipil 6(1):83-95.

Friska Ayu, Denis Fidita K, and Muslikha R. Nourma. 2019. "Pengaruh Program K3 Terhadap Produktivitas Kerja Pada Operator Alat Berat Di PT BJTI Kota Surabaya." Business and Finance Journal 4 No. 2.

Hakim, Abdul. 2014. Dasar-Dasar Hukum Ketenagakerjaan Di Indonesia. bandung: PT Citra Aditya Bakti.

International Labour Organization. 2020. "Dalam Menghadapi Pandemi: Memastikan Keselamatan Dan Kesehatan Di Tempat Kerja." Labour Administration, Labour Inspection and Occupational Safety and Health Branch (LABADMIN/OSH) Route 1-52.

Jati Kusuma, Ibrahim, and Ismi Darmastuti. 2010. "Bitratex Industries Semarang." Jurnal Studi Manajemen \& Organisasi 7(1):37-60.

Mangkunegara. 2017. Manajemen Sumber Daya Manusia Perusahaan. bandung: remaja rosdakarya.

Mardhatillah, Anggianika. 2017. "Evaluasi Penerapan Sistem Manajemen Keselamatan Dan Kesehatan Kerja (SMK3) Di PT. Semen Padang.” HIGEIA (Journal of Public Health Research and Development) 1(1):29-35.

Mardi Astutik, and Retno Catur Kusuma Dewa. 2019. "Pengaruh Keselamatan Dan Kesehatan Kerja (K3) Dan Lingkungan Kerja Terhadap Produktivitas Kerja Karyawan." Management and Business Review 3:1-8.

Marshal, Daniel, Kerenhapukh milka tarmadi putri, and niken febriana dwi. 2020. "Peran Negara Atas Perlindungan Hukum Tenaga Kerja Indonesia Pada Masa Pandemi Covid-19." Jurnal Syntax Transformation 1.

Perdana, R. C., M. R. Agustino, and ... 2020. “Adaptasi Dan Kebiasaan Baru Human Resource Department Di Masa Pandemik Covid-19.” Business ... 2(3):201-4.

Sukanta, Dessy Agustina Sari, and Anwar Musadad. 2020. "Pelatihan Sistem Manajemen K3 Dan New Normal." Prosiding Seminar Nasional Rekarta 2020 $2-7$.

Wahyuni, Nining, Bambang Suyadi, and Wiwin Hartanto. 2018. "Pengaruh Keselamatan Dan Kesehatan Kerja (K3) Terhadap Produktivitas Kerja Karyawan Pada Pt. Kutai Timber Indonesia." JURNAL PENDIDIKAN EKONOMI: Jurnal Ilmiah Ilmu Pendidikan, Ilmu Ekonomi Dan Ilmu Sosial 12(1):99. doi: 10.19184/jpe.v12i1.7593. 


\section{Website:}

Fahrul A., (BSN). (2020). Pentingnya Penerapan SMK3 Dalam Era New Normal. https://www.bsn.go.id/main/berita/detail/11149/pentingnya-penerapan-smk3dalam-era-new-normal- diakses 9 September 2020 pkl 12.30 WIB.

Gugus Tugas Percepatan Penanganan Virus Covid-19 Provinsi Sumatera Barat. https://www.sumbarprov.go.id/home/news/19417-info-covid-19-sumaterabarat- diakses 3 September 2020 pukul 14.30 WIB 